\title{
Availability and spatial variability of copper, iron, manganese and zinc in soils of the State of Ceará, Brazil ${ }^{1}$
}

\author{
Disponibilidade e variabilidade espacial de cobre, ferro, manganês e zinco em solos \\ do Estado do Ceará, Brasil
}

Mara Lucia Jacinto Oliveiraa ${ }^{2 *}$, Gustavo Souza Valladares ${ }^{2}$, Johnston Silva Vieira ${ }^{2}$ and Ricardo Marques Coelho ${ }^{3}$

\begin{abstract}
The aim of the present work was to: (i) determine and map the micronutrient content (copper - $\mathrm{Cu}$, iron - Fe, manganese - Mn and zinc - Zn) in soils of the State of Ceará; (ii) evaluate soil attributes related to micronutrient availability; and (iii) evaluate, by ordinary kriging, the spatial dependence of the micronutrient content. The study area is located in the central region of Ceará, in the basin of the River Banabuiú. Soil samples were collected in the surface and subsurface layers to determine the chemical attributes, granulometry, and micronutrient content, extracted with Mehlich-1 solution. The sites of the principal types of soil in the region were spatialised and the results submitted to descriptive analysis and Pearson correlation analysis. The semivariograms with the best fit were tested using the ordinary kriging method, and the maps of spatial variability were prepared. The highest values for the mean, maximum and minimum levels of $\mathrm{Cu}$ and $\mathrm{Fe}$ are found in the subsurface layers, while for $\mathrm{Mn}$ and $\mathrm{Zn}$, they are found in the surface layers. In the surface layers, the majority of soils present $\mathrm{Fe}, \mathrm{Mn}$ and $\mathrm{Zn}$ in levels suitable for agricultural production, while the levels of $\mathrm{Cu}$ are classified as medium to low. The micronutrients showed a significant positive correlation, especially with the soil attributes and with each other. $\mathrm{Cu}, \mathrm{Fe}, \mathrm{Mn}$ and $\mathrm{Zn}$ are classified as having medium to strong spatial dependence in the surface and subsurface layers.
\end{abstract}

Key words: Cationic micronutrients. Geostatistics. Ordinary kriging. Soils of the semi-arid region.

\begin{abstract}
RESUMO - O presente trabalho teve por objetivos: (i) determinar e mapear os teores dos micronutrientes (cobre - Cu, ferro - Fe, manganês - Mn e zinco - Zn) em solos do Estado do Ceará; (ii) avaliar atributos do solo relacionados à disponibilidade dos micronutrientes; (iii) avaliar, por krigagem ordinária, a dependência espacial dos teores dos micronutrientes. A área estudada está localizada na região central do Ceará, na bacia do Rio Banabuiú. Amostras de solo foram coletadas, nas camadas superficiais e subsuperficiais, para determinação dos atributos químicos, granulometria, e dos teores de micronutrientes, extraídos com solução de Mehlich-1. Os pontos dos principais tipos de solos da região foram espacializados. Os resultados foram submetidos a análises descritivas e análises de correlação de Pearson. Foram testados os semivariogramas que tiveram os melhores ajustes, utilizando o método de krigagem ordinária, e elaborados os mapas de variabilidade espacial. Os maiores teores de média, máximo e mínimo para $\mathrm{Cu}$ e Fe se encontram nas camadas subsuperficiais, e para $\mathrm{Mn}$ e $\mathrm{Zn}$ nas camadas superficiais. Nas camadas superficiais, a maioria dos solos apresentam $\mathrm{Fe}, \mathrm{Mn}$ e $\mathrm{Zn}$ em teores adequados à produção agrícola, e Cu apresenta teores nas classes médio a baixo. Os micronutrientes apresentaram correlações significativas positivas, principalmente, com os atributos dos solos e entre si. $\mathrm{Cu}, \mathrm{Fe}, \mathrm{Mn}$ e $\mathrm{Zn}$ apresentam dependência espacial classificada como média a forte, nas camadas superficiais e subsuperficiais.
\end{abstract}

Palavras-chaves: Micronutrientes catiônicos. Geoestatística. Krigagem ordinária. Solos do semiárido.

\footnotetext{
DOI: $10.5935 / 1806-6690.20180042$

*Author for correspondence

Received for publication in 18/04/2017; approved 26/10/2017

${ }^{1}$ Parte da Dissertação de Mestrado do terceiro autor apresentada na Universidade Federal do Piauí, pesquisa apoiada pela Petrobrás, CAPES e CNPq

${ }^{2}$ Universidade Federal do Piauí, Teresina-PI, Brasil, maraljoliveira@hotmail.com, valladares@ufpi.edu.br, vieira_agrojs@outlook.com

${ }^{3}$ Instituto Agronômico de Campinas, Jardim Guanabara, Campinas-SP, Brasil, rmcoelho@iac.sp.gov.br
} 


\section{INTRODUCTION}

Knowledge of the relationship between soil fertility and agricultural productivity is central to agriculture. According to Novais et al. (2007), each tonne of mineral fertiliser applied to one hectare, following the principles for maximum efficiency, is equivalent in production to four new hectares without fertiliser. In areas of agriculture generally restricted to nitrogen-phosphorus-potassium (NPK) fertiliser, the demand for micronutrients under the various conditions of soil, climate and crops becomes important.

According to Sharma et al. (2013), the availability of micronutrients is influenced by several factors: soil type and chemical attributes, chemical speciation and concentration, soil $\mathrm{pH}$, nutrient cycling, the element source and the nature of the microorganisms. Investigating the shortage of these elements, as well as their variability in relation to soil attributes, allows their availability to be predicted and promotes the efficient use of correctives and fertilisers (BIONDI et al., 2011; PIERANGELI et al., 2009).

A study of the variability of soil attributes is a basic tool for interpreting the spatial distribution of data, with a strong impact on results and decision-making (MELO et al., 2016; VALLADARES et al., 2009). Geostatistics is defined as a set of spatial modelling techniques, including probabilistic sampling, which allow surfaces to be mapped and data to be gauged at unsampled sites, taking into account the spatial and/or temporal behaviour of a particular phenomenon and reducing any error in this evaluation (LADO; HENGL; REUTER, 2008). Such techniques make it possible to understand the continuity of a variable of interest throughout the study area, demonstrating the spatial variation of the phenomenon through maps of spatial variability (CHAVES; FARIAS, 2009).

Ryan et al. (2013) found that studies of micronutrient mapping by geostatistics facilitated the definition of suitable management practices for each site, improving the efficiency of fertiliser application, which could reduce cultivation costs. Tekin et al. (2011) found the spatial variability of iron $(\mathrm{Fe})$, manganese $(\mathrm{Mn})$, copper $(\mathrm{Cu})$ and zinc $(\mathrm{Zn})$ to be related to the properties of the soil and the maize crop. The spatial heterogeneity of the studied variables was influenced by the difference in soil texture throughout the area under study. Valladares et al. (2009) found a high positive spatial correlation between the $\mathrm{Cu}$ and $\mathrm{Zn}$ content of soils in the State of São Paulo, as well as a relationship between content and land use, where higher levels were found in areas of vineyards compared to native soils.
Consequently, the aims of this study are to determine and map the micronutrient content $(\mathrm{Cu}, \mathrm{Fe}, \mathrm{Mn}$ and $\mathrm{Zn}$ ) of soils in the interior of the State of Ceará; to evaluate soil attributes possibly related to micronutrients; to evaluate, by ordinary kriging, the spatial dependence of the micronutrient content; and to verify the spatial distribution of the micronutrient content.

\section{MATERIAL AND METHODS}

The study area is located in the central region of the State of Ceará, in the basin of the River Banabuiú, between $5^{\circ} 21^{\prime}$ and $5^{\circ} 53^{\prime} \mathrm{S}$ and $39^{\circ} 18^{\prime}$ and $39^{\circ} 51^{\prime} \mathrm{W}$. It has a hot tropical semi-arid climate with low rainfall. The total area is around 149,000 hectares, and includes part of the districts of Pedra Branca, Senador Pompeu, Mombaça and Piquet Carneiro (Figure 1) (AQUINO et al., 2016). Land use is distributed as follows: urban area (1\%), agriculture - predominantly maize $(8 \%)$, pasture $(26 \%)$ and riparian and caatinga vegetation (64\%) (GUIMARÃES; VALLADARES; MARTINS, 2016).

Figure 1 - Location of the study area and sampling points of the soils in the central region of Ceará

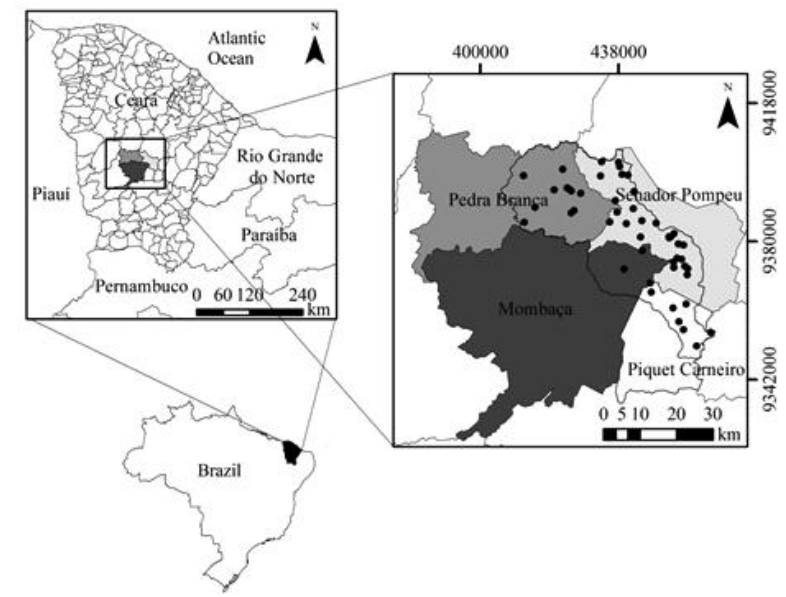

The study was based on research into morphological characterisation and pedological classification in soil profiles of the study area, presented by Aquino et al. (2016) and Valladares (2014). The geographic extent of the soils in the study area indicates a predominance of the following orders as the major components in associations: Red Argisols (53\%) and Litholic Neosols (27\%), comprising $80 \%$ of the area. With less spatial expression, are the Red-Yellow Argisols (5.2\%), Haplic Cambisols (4.6\%), Argiluvic Chernosols 
(3.1\%), Haplic Planosols (2.3\%) and other soils, that as major components comprise less than $2 \%$ of the study area.

Points of interest were identified using a morphometric image, formed by a false colour composition including terrain altimetry, slope and curvature. Samples were collected for physical and chemical analysis at a total of 49 points (Figure 1) in the surface and subsurface layers, at depths corresponding to the petrogenetic horizons. The $A$ horizon was considered for the surface samples, and the $B$ and $E$ horizons (when present) for the subsurface samples, or the $C$ horizon for the Neosols.

The granulometric and chemical analyses were carried out for $\mathrm{pH}\left(\mathrm{H}_{2} \mathrm{O}\right)$, calcium $\left(\mathrm{Ca}^{+2}\right)$, magnesium $\left(\mathrm{Mg}^{+2}\right)$, potassium $\left(\mathrm{K}^{+}\right)$, sodium $\left(\mathrm{Na}^{+}\right)$, sum of bases (SB), aluminum $\left(\mathrm{Al}^{+3}\right)$, cation exchange capacity (CEC) at $\mathrm{pH} 7.0$, percentage base saturation (V\%), $\mathrm{P}$, and organic carbon (OC) converted to organic matter (OM), as per Embrapa (2009). The micronutrients were extracted by a solution of $0.05 \mathrm{~mol} \mathrm{~L}^{-1} \mathrm{HCl}+0.0125 \mathrm{~mol} \mathrm{~L}^{-1} \mathrm{H}_{2} \mathrm{SO}_{4}$ (Mehlich-1), as per Embrapa (2009), and quantified by atomic absorption spectrophotometry.

Micronutrient availability was evaluated following the classification proposed by Alvarez et al. (1999) for the State of Minas Gerais, adapted for three classes and using the same Mehlich-1 extractor (Table 1).

Table 1 - Classes for the interpretation of micronutrient availability extracted by the Mehlich-1 method

\begin{tabular}{lcccc}
\hline \multirow{2}{*}{$*$ Class } & $\mathrm{Cu}$ & $\mathrm{Fe}$ & $\mathrm{Mn}$ & $\mathrm{Zn}$ \\
\cline { 2 - 5 } & \multicolumn{4}{c}{$\mathrm{mg} \mathrm{dm}^{-3}$} \\
\hline Low & $\leq 0.7$ & $\leq 18$ & $\leq 5$ & $\leq 0.9$ \\
Medium & $0.8-1.2$ & $19-30$ & $6-8$ & $1.0-1.5$ \\
Good & $\geq 1.3$ & $\geq 31$ & $\geq 9$ & $\geq 1.6$ \\
\hline *Adapted fromAlvarez et al.(1999)
\end{tabular}

The micronutrient content was submitted to descriptive statistical analysis to determine the values for the minimum, mean, maximum, standard deviation and coefficient of variation. Pearson's linear correlation analysis $(<0.05)$ between the levels of $\mathrm{Cu}, \mathrm{Fe}, \mathrm{Mn}$, and $\mathrm{Zn}$ and the chemical attributes and granulometry of the soil was applied using the ASSISTAT v 7.7 statistical software, (SILVA; AZEVEDO, 2016).

The semivariograms were adjusted using the GS plus v 7.0 software, (GAMMA DESIGN SOFTWARE, 2004), and interpolated using the ordinary kriging method, which estimates the values under conditions of non-bias and with minimum deviations from the estimated values, i.e. with minimal variance (VIEIRA et al., 2002).

From the compiled data, a geo-referenced database was constructed containing all the necessary information for the proposed analyses. The spatial distribution maps were plotted using ordinary kriging (VIEIRA et al., 2002) with the aid of the ArcGIS Desktop v 10.2 geographic information software (ENVIRONMENTAL SYSTEMS RESEARCH INSTITUTE, 2014).

An analysis to detect discrepant values (Outlier maximum/minimum) was carried out using Equation 1 to remove these values and prepare the maps, as described by Cahn, Hummel and Broer (1994).

Outlier $\max / \min =X \pm 4 \sigma$

where:

$X=$ mean;

$\sigma=$ standard deviation

The degree of dependence (DD), which is the percentage proportion of the partial sill $(\mathrm{C} 1)$ relative to the sill $(\mathrm{C} 0+\mathrm{C} 1)$ (Equation 2), was calculated considering weak dependence as $<25 \%$, moderate dependence from 26 to $75 \%$ and strong dependence $>75 \%$, as per Zimback (2001).

$D D=(C 1 /(C 1+C 0)) * 100$

\section{RESULTS AND DISCUSSION}

For each determination of the micronutrients under study, the coefficients of variation were high in the surface and subsurface layers (Table 2); this may be related to the diversity of lithology and relief. According to Valladares (2014), the study area is inserted in a domain characterised by great lithological complexity, with records of folding accompanied by metamorphism and the presence of basic rocks alternating with long erosive phases. Consequently, the soils classified in the area are characteristic of soil association, with great variations in their physical and chemical properties.

The greatest values for mean, maximum and minimum $\mathrm{Cu}$ and $\mathrm{Fe}$ content were found in the subsurface layers (Table 2). This may indicate local lithology as the main source of $\mathrm{Cu}$ and $\mathrm{Fe}$ in the soils. The region presents intrusions composed of basalts, granites, metagabbros and syenites (COMPANHIA DE PESQUISA DE RECURSOS MINERAIS, 2014). According to Stevenson and Cole (1999), basalt intrusions are mainly composed of ferromagnesian minerals and sulphides, the latter having a high geochemical affinity for $\mathrm{Cu}$. 
Table 2 - Mean, maximum and minimum values for micronutrient content, standard deviation and coefficient of variation of soils sampled in the central region of Ceará

\begin{tabular}{|c|c|c|c|c|c|c|}
\hline \multirow{2}{*}{ Micronutrient } & \multirow{2}{*}{ Unit } & \multirow{2}{*}{ Mean } & \multicolumn{2}{|c|}{ Value } & \multirow{2}{*}{ SD } & \multirow{2}{*}{$\mathrm{CV}(\%)$} \\
\hline & & & Max. & Min. & & \\
\hline \multicolumn{7}{|c|}{ Surface samples } \\
\hline $\mathrm{Cu}$ & \multirow{4}{*}{$\mathrm{mg} \mathrm{dm}{ }^{-3}$} & 0.90 & 2.96 & 0 & 0.61 & 68.03 \\
\hline $\mathrm{Fe}$ & & 50.16 & 283.3 & 6.1 & 45.69 & 91.10 \\
\hline Mn & & 55.42 & 246.3 & 0.2 & 49.90 & 90.03 \\
\hline $\mathrm{Zn}$ & & 2.94 & 21.81 & 0.78 & 2.70 & 91.85 \\
\hline \multicolumn{7}{|c|}{ Subsurface samples } \\
\hline $\mathrm{Cu}$ & \multirow{4}{*}{$\mathrm{mg} \mathrm{dm}{ }^{-3}$} & 0.99 & 3.03 & 0.09 & 0.60 & 60.41 \\
\hline $\mathrm{Fe}$ & & 59.18 & 500.90 & 7.10 & 57.96 & 97.95 \\
\hline Mn & & 18.13 & 202.00 & 0.00 & 23.34 & 128.73 \\
\hline $\mathrm{Zn}$ & & 1.53 & 4.10 & 0.00 & 0.75 & 48.95 \\
\hline
\end{tabular}

Min. $=$ Minimum; Max. $=$ Maximum; $\mathrm{SD}=$ Standard deviation $; \mathrm{CV}=$ Coefficient of variation

Mn and $\mathrm{Zn}$ showed the opposite behaviour to that found for $\mathrm{Cu}$ and $\mathrm{Fe}$, with the highest values for mean, maximum and minimum content found in the surface layers (Table 2). Mn and Zn also occur in ferromagnesian minerals, as isomorphic substitutes of the $\mathrm{Fe}$ and $\mathrm{Mg}$ in the mineral structure (STEVENSON; COLE, 1999). However, the high bioavailability of these elements at the mean $\mathrm{pH}$ value determined in the soil samples ( $\mathrm{pH}=6.0)$ (NOVAIS et al., 2007) may have favoured the uptake and cycling of soil micronutrients by the plants, increasing their content in the surface layers (GIONGO et al., 2011; LIMA et al., 2015; SHARMA et al., 2013).

Morais, Oliveira and Maia (2014), analysing Zn and $\mathrm{Mn}$ in samples of the surface layer of soil under caatinga, found values similar to those presented in this study. In addition, Sobrado (2013) found concentrations in the leaves of native caatinga species that were close to or within the satisfactory level for $\mathrm{Zn}$ and $\mathrm{Mn}$ respectively, demonstrating the high adaptive capacity of the vegetation in maintaining the balance of micronutrient uptake for soil content, in the case of $\mathrm{Zn}$ below the critical level, and in the case of Mn at high levels.

On the other hand, since agriculture in the region uses applications restricted to macronutrients (AQUINO et al., 2016), in the cultivated areas that were sampled, impurities in NPK fertilisers and correctives become a secondary source of micronutrient input to the soils and of their concentration in the surface layers (CARVALHO; NASCIMENTO; BIONDI, 2012).

From the percentage distribution of micronutrients (Table 3) according to the classes for agricultural interpretation adapted from Alvarez et al. (1999), it can be seen that for $\mathrm{Fe}, \mathrm{Mn}$ and $\mathrm{Zn}$ in the surface layers, the largest percentage of the data $(66.67 \%, 90.33 \%$ and $90.33 \%$ respectively) was concentrated in the good class of content (>31, >9 and >1.6 $\mathrm{mg} \mathrm{kg}^{-1} \mathrm{Fe}, \mathrm{Mn}$ and $\mathrm{Zn}$ ) (Table $1)$, i.e. suitable for the vast majority of crops. For the same sequence of elements, only $33.33 \%, 9.69 \%$ and $19.36 \%$ of the sampled soils had content classified as medium or low ( $<30,<8$ and $<1.5 \mathrm{mg} \mathrm{kg}^{-1} \mathrm{Fe}, \mathrm{Mn}$ and $\mathrm{Zn}$ respectively) (Table 1). However, $\mathrm{Cu}$ displayed the majority $(75.27 \%)$ of the levels classified as medium or low $\left(<1.2 \mathrm{mg} \mathrm{kg}^{-1} \mathrm{Cu}\right)$ (Table 1), with only $24.76 \%$ of the content concentrated in the good class $\left(>1.3 \mathrm{mg} \mathrm{kg}^{-1} \mathrm{Cu}\right.$ ) (Table 1).

In the subsurface layers, the percentage distribution of micronutrients was similar to that in the surface layers, with smaller differences between the predominant class and the other classes. Except for $\mathrm{Zn}$, which despite presenting the highest percentage content determined in the sampled soils in the good class $(45.60 \%)$, the sum of the middle and low classes totalled $54.40 \%$. According to Camargo (2006), this can be explained by the low mobility of $\mathrm{Zn}$ in the soil profile, even at $\mathrm{pH}$ values greater than 5.0.

As agronomic interests mainly consider the surface layers, where the larger part of the plant root system is concentrated, the soils of the central region of Ceará largely present a micronutrient content suitable for the majority of crops. In addition, the fertilisers and correctives marketed in the Northeast, represent an important source of micronutrients, which should not be ignored in fertilisation programs (BIONDI et al., 2011; CARVALHO; NASCIMENTO; BIONDI, 2012). 
According to the Pearson correlations (Table 4), the micronutrients presented mostly significant positive coefficients with the soil attributes. The correlation analysis between the micronutrients and the soil attributes revealed that the significant correlation coefficients were low, i.e. generally less than 0.50 , indicating a low linear dependence between the variables.

Table 3 - Percentage distribution of micronutrients in the surface and subsurface layers of soils of the central region of the State of Ceará

\begin{tabular}{|c|c|c|c|c|}
\hline \multirow{2}{*}{ Class* } & $\mathrm{Cu}$ & $\mathrm{Fe}$ & $\mathrm{Mn}$ & $\mathrm{Zn}$ \\
\hline & 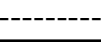 & -------- & 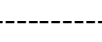 & -_--_- \\
\hline \multicolumn{5}{|c|}{ Surface layers } \\
\hline Low & 47.31 & 23.65 & 4.30 & 1.07 \\
\hline Medium & 27.96 & 9.68 & 5.38 & 18.28 \\
\hline Good & 24.73 & 66.67 & 90.32 & 80.65 \\
\hline Total & 100 & 100 & 100 & 100 \\
\hline \multicolumn{5}{|c|}{ Subsurface layers } \\
\hline Low & 40.00 & 13.60 & 32.80 & 16.00 \\
\hline Medium & 27.20 & 16.80 & 7.20 & 38.40 \\
\hline Good & 32.80 & 69.60 & 60.00 & 45.60 \\
\hline Total & 100 & 100 & 100 & 100 \\
\hline
\end{tabular}

*Adapted fromAlvarez et al. (1999)

Table 4 - Pearson correlation between the micronutrients and soil attributes in the surface and subsurface layers of the central region of Ceará

\begin{tabular}{lcccc}
\hline \multirow{2}{*}{ Parameter } & $\mathrm{Cu}$ & $\mathrm{Fe}$ & $\mathrm{Mn}$ & $\mathrm{Zn}$ \\
\cline { 2 - 4 } Sand & \multicolumn{2}{c}{ Surface layers } & $-0.18^{\mathrm{ns}}$ \\
Silt & $-0.66^{* *}$ & $-0.23^{*}$ & $-0.37^{* *}$ & $0.19^{\mathrm{ns}}$ \\
$\mathrm{Clay}$ & $0.48^{* *}$ & $0.46^{* *}$ & $0.24^{*}$ & $0.23^{*}$ \\
$\mathrm{pH}$ & $0.67^{* *}$ & $-0.02^{\mathrm{ns}}$ & $0.37^{* *}$ & $0.32^{* *}$ \\
$\mathrm{P}$ & $0.31^{* *}$ & $-0.26^{*}$ & $0.39^{* *}$ & $0.29^{* *}$ \\
$\mathrm{~K}$ & $-0.01^{\mathrm{ns}}$ & $0.06^{\mathrm{ns}}$ & $0.06^{\mathrm{ns}}$ & $0.49^{* *}$ \\
$\mathrm{Na}$ & $0.08^{\mathrm{ns}}$ & $-0.06^{\mathrm{ns}}$ & $0.62^{* *}$ & $0.01^{\mathrm{ns}}$ \\
$\mathrm{Ca}$ & $0.46^{* *}$ & $0.34^{* *}$ & $-0.03^{\mathrm{ns}}$ & $0.45^{* *}$ \\
$\mathrm{Mg}$ & $0.51^{* *}$ & $0.04^{\mathrm{ns}}$ & $0.44^{* *}$ & $0.12^{*}$ \\
$\mathrm{Al}$ & $0.58^{* *}$ & $0.16^{\mathrm{ns}}$ & $0.28^{* *}$ & $-0.24^{*}$ \\
$\mathrm{SB}$ & $0.24^{*}$ & $0.30^{*}$ & $-0.30^{* *}$ & $0.41^{* *}$ \\
$\mathrm{CEC}(\mathrm{pH})$ & $0.56^{* *}$ & $0.16^{\mathrm{ns}}$ & $0.43^{* *}$ & $-0.01^{\mathrm{ns}}$ \\
$\mathrm{V} \%$ & $0.25^{*}$ & $0.06^{\mathrm{ns}}$ & $0.24^{*}$ & $0.38^{* *}$ \\
$\mathrm{OM}$ & $0.41^{* *}$ & $0.05^{\mathrm{ns}}$ & $0.47^{* *}$ & $0.65^{* *}$ \\
$\mathrm{Cu}$ & $-0.08^{\mathrm{ns}}$ & $0.11^{\mathrm{ns}}$ & $0.58^{* *}$ & $0.12^{\mathrm{ns}}$ \\
$\mathrm{Fe}$ & 1.00 & $0.53^{* *}$ & $0.23^{*}$ & $-0.06^{\mathrm{ns}}$ \\
$\mathrm{Mn}$ & & 1.00 & $-0.05^{\mathrm{ns}}$ & $0.63^{* *}$ \\
$\mathrm{Zn}$ & & 1.00 & 1.00 \\
\hline
\end{tabular}


Continuation Table 4

\begin{tabular}{lcccc}
\hline & \multicolumn{2}{c}{ Subsurface layers } \\
\hline Sand & $-0.44^{* *}$ & $0.26^{* *}$ & $-0.21^{*}$ & $-0.02^{\text {ns }}$ \\
Silt & $0.33^{* *}$ & $0.18^{\text {ns }}$ & $0.45^{* *}$ & $0.22^{*}$ \\
Clay & $0.44^{* *}$ & $-0.23^{* *}$ & $0.05^{\text {ns }}$ & $-0.04^{\text {ns }}$ \\
pH & $0.47^{* *}$ & $0.13^{\text {ns }}$ & $0.54^{* *}$ & $0.48^{* *}$ \\
$\mathrm{P}$ & $0.12^{\text {ns }}$ & $-0.04^{\text {ns }}$ & $0.28^{* *}$ & $0.38^{* *}$ \\
$\mathrm{~K}$ & $-0.06^{\text {ns }}$ & $-0.11^{\text {ns }}$ & $0.03^{\text {ns }}$ & $0.13^{\text {ns }}$ \\
$\mathrm{Na}$ & $0.05^{\text {ns }}$ & $0.24^{* *}$ & $0.20^{*}$ & $0.10^{\text {ns }}$ \\
$\mathrm{Ca}$ & $0.51^{* *}$ & $0.35^{* *}$ & $0.51^{* *}$ & $0.46^{* *}$ \\
$\mathrm{Mg}$ & $0.52^{* *}$ & $0.36^{* *}$ & $0.45^{* *}$ & $0.25^{* *}$ \\
$\mathrm{Al}$ & $-0.05^{\text {ns }}$ & $-0.36^{* *}$ & $-0.23^{*}$ \\
$\mathrm{SB}$ & $-0.17^{\text {ns }}$ & $0.43^{* *}$ & $0.53^{* *}$ & $0.41^{* *}$ \\
$\mathrm{CEC}(\mathrm{pH} 7)$ & $0.54^{* *}$ & $0.19^{*}$ & $0.47^{* *}$ & $0.44^{* *}$ \\
$\mathrm{~V} \%$ & $0.31^{* *}$ & $0.16^{\mathrm{ns}}$ & $0.55^{* *}$ & $0.37^{* *}$ \\
$\mathrm{OM}$ & $0.49^{* *}$ & $0.24^{* *}$ & $0.54^{* *}$ & $0.43^{* *}$ \\
$\mathrm{Cu}$ & $0.21^{* *}$ & $0.41^{\text {ns }}$ & $0.63^{* *}$ & $0.51^{* *}$ \\
$\mathrm{Fe}$ & 1.00 & 1.00 & $0.24^{* *}$ & $0.49^{* *}$ \\
$\mathrm{Mn}$ & & 1.00 & $0.65^{* *}$ \\
$\mathrm{Zn}$ & & & 1.00 \\
\hline
\end{tabular}

**, * e ns: significant at $1 \%$, at $5 \%$ and not significant respectively

For Fe, Mn and Zn (Table 4), the highest correlation coefficients were determined between the micronutrients themselves and between the chemical attributes of the soil at both depths, when compared to the coefficients calculated for the physical attributes of the soil. Under the conditions of the study area, it can be inferred that the micronutrients are to a greater degree related to the chemical components of the soil than to the granulometry of the soil.

$\mathrm{Cu}$ presented a negative correlation with sand and a positive correlation with clay (Table 4). Furthermore, the micronutrient showed a non-significant correlation with $\mathrm{OM}$ in the surface layers. Clay and $\mathrm{OM}$ are the main components involved in $\mathrm{Cu}$ retention in the soil (CAMARGO, 2006). However, in the case of the study area, the climate is highly favourable to the decomposition of OM. These factors may have resulted in the nonsignificant correlation between $\mathrm{Cu}$ and $\mathrm{OM}$, the positive correlation between $\mathrm{Cu}$ and clay, and the negative correlation with sand, a fraction with a restricted sorption complex for adsorbing the micronutrient, favouring leaching of the $\mathrm{Cu}$ (NOVAIS et al., 2007).

As shown above, the study area is very extensive, partially covering four municipal districts. Despite the large distances between the collected samples, moderate and strong spatial dependencies were found (ZIMBACK, 2001), with a good fit of the semivariograms to the content of each micronutrient studied in the surface and subsurface layers (Table 5 and Figure 2).

The semivariograms were adjusted by the Gaussian model for $\mathrm{Cu}, \mathrm{Fe}$ and $\mathrm{Mn}$ in the surface layers, and $\mathrm{Mn}$ and $\mathrm{Zn}$ in the subsurface layers and by the exponential model for $\mathrm{Zn}$ in the surface layers, and $\mathrm{Cu}$ and $\mathrm{Fe}$ in the subsurface layers. The range was higher for the $\mathrm{Cu}$ and Fe content in the surface horizons $(41.25$ and $72.16 \mathrm{~km}$ respectively), demonstrating the spatial dependence of these micronutrients even over great distances. However, the range was ten times smaller for $\mathrm{Cu}$ and $\mathrm{Fe}$ in the subsurface horizons and for $\mathrm{Mn}$ and $\mathrm{Zn}$ at both depths, showing that spatial dependence is significant, but occurs over smaller distances (Table 5).

Comparing the maps in Figure 3, which show micronutrient distribution in the surface and subsurface layers, a certain similarity can be seen for the $\mathrm{Cu}$ and Fe content at both depths, showing the like behaviour of these elements. This confirms the hypothesis that the parent material of the soil would be the most important source of this micronutrient content, since 
Figure 2 - Semivariograms for micronutrient content in the surface layers (A, B, C and D) and subsurface layers (E, F, G and H), in soils of the central region of Ceará
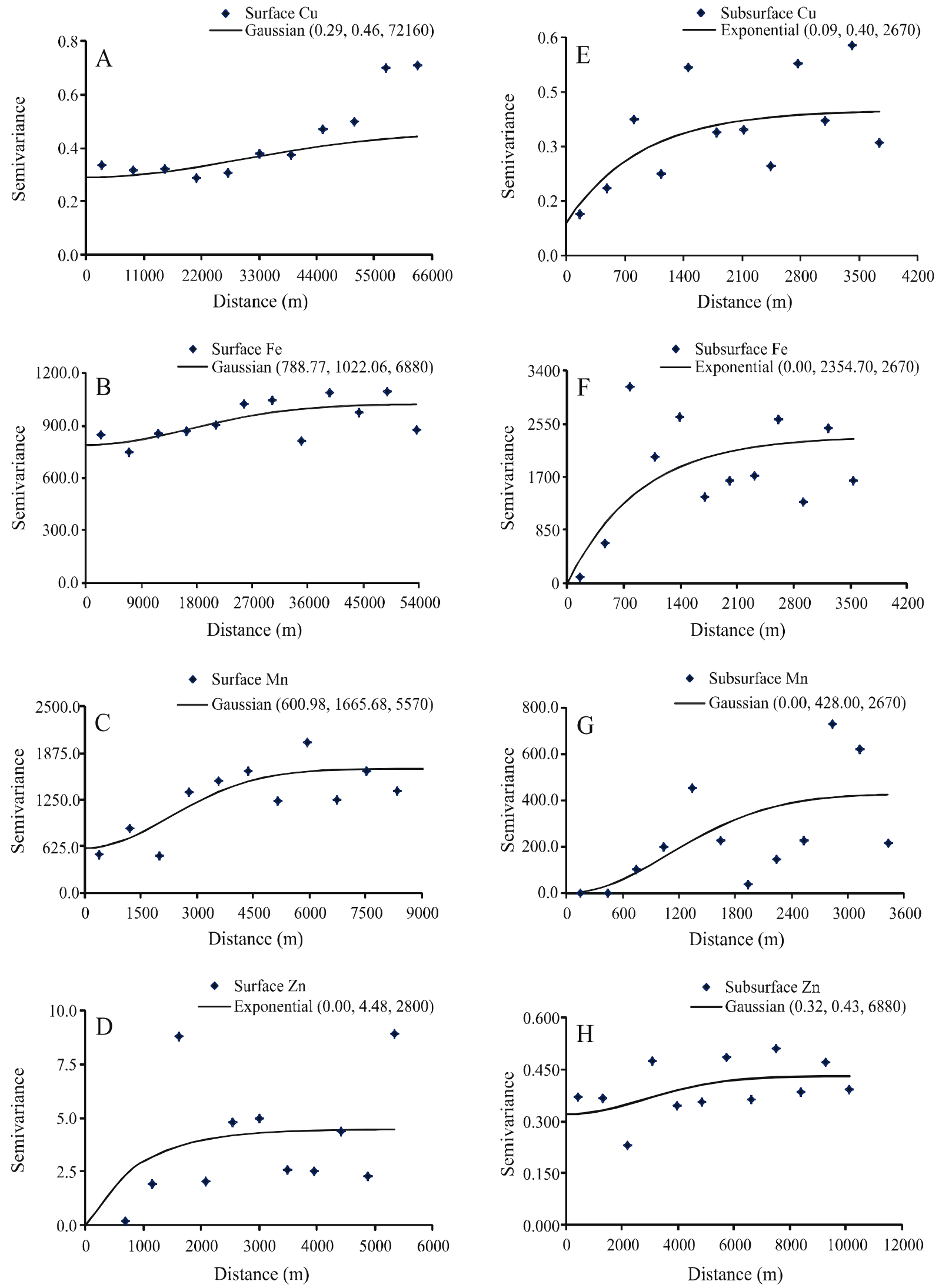
Figure 3 - Spatial distribution of the micronutrient content in the surface layers (A, B, C and D) and subsurface layers (E, F, G and H)
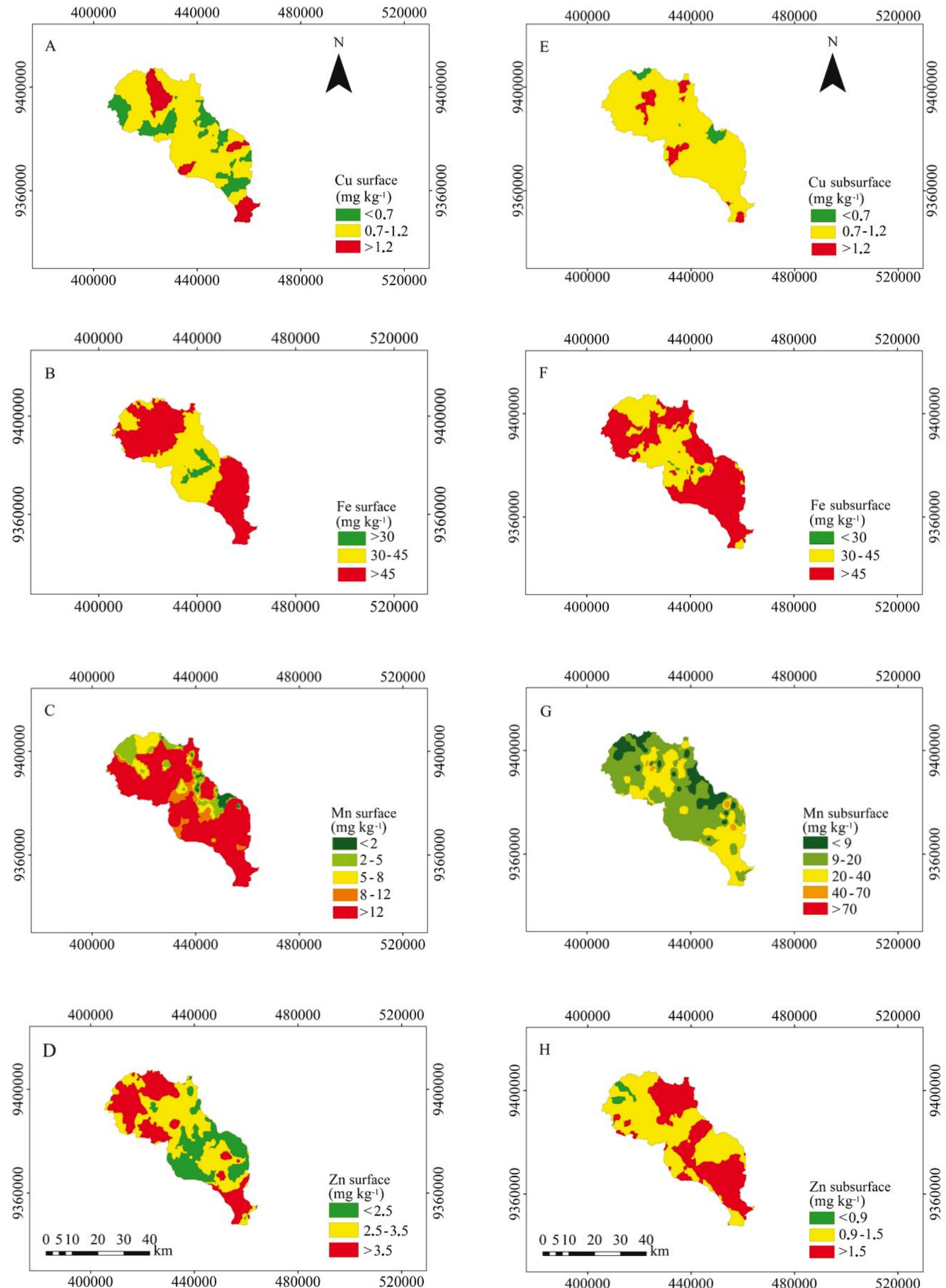
Table 5 - Models of semivariograms adjusted for the attributes in the surface and subsurface layers of soils in the central region of Ceará

\begin{tabular}{|c|c|c|c|c|c|c|}
\hline Micronutrient & Model & $\mathrm{C} 0$ & $\mathrm{C} 1$ & Range $(\mathrm{km})$ & \multicolumn{2}{|c|}{-- } \\
\hline \multicolumn{7}{|c|}{ Surface layers } \\
\hline $\mathrm{Cu}$ & Gaussian & 0.29 & 0.46 & 72.16 & 61.33 & Moderate \\
\hline $\mathrm{Fe}$ & Gaussian & 788.77 & 1022.06 & 41.25 & 56.44 & Moderate \\
\hline $\mathrm{Mn}$ & Gaussian & 600.98 & 1665.68 & 5.57 & 73.49 & Moderate \\
\hline $\mathrm{Zn}$ & Exponential & 0.00 & 4.48 & 2.80 & 100.00 & Strong \\
\hline \multicolumn{7}{|c|}{ Subsurface layers } \\
\hline$\overline{\mathrm{Cu}}$ & Exponential & 0.09 & 0.40 & 2.67 & 81.63 & Strong \\
\hline $\mathrm{Fe}$ & Exponential & 0.00 & 2354.70 & 2.67 & 100.00 & Strong \\
\hline $\mathrm{Mn}$ & Gaussian & 0.00 & 428.88 & 2.67 & 100.00 & Strong \\
\hline $\mathrm{Zn}$ & Gaussian & 0.32 & 0.43 & 6.88 & 57.33 & Moderate \\
\hline
\end{tabular}

C0: nugget effect; C1: sill; GD: degree of spatial dependence

the highest concentrations are found in the subsurface layers (COMPANHIA DE PESQUISA DE RECURSOS MINERAIS, 2014, STEVENSON; COLE, 1999).

The spatial distribution of $\mathrm{Mn}$ and $\mathrm{Zn}$ at both depths is quite different, indicating the surface enrichment of these elements by such natural processes as nutrient cycling (GIONGO et al., 2011; LIMA et al., 2015; MELO et al., 2016; MLAMBO; NYATHI, 2008). The greater correlation between the $\mathrm{Mn}$ and $\mathrm{Zn}$ content with the soil $\mathrm{OM}$ in the surface horizons (Table 4), and the high levels of these two micronutrients in the surface layers, can be explained by the surface horizons of the soil containing more OM.

\section{CONCLUSIONS}

1. The highest values for the mean, maximum and minimum levels of $\mathrm{Cu}$ and $\mathrm{Fe}$ are found in the subsurface layers, while for $\mathrm{Mn}$ and $\mathrm{Zn}$, they are found in the surface layers;

2. The Fe, Mn and $\mathrm{Zn}$ content in the surface layers of the majority of soils are suitable for agricultural production, while the $\mathrm{Cu}$ content is classified as medium to low;

3. The micronutrients displayed significant positive correlations, the majority with the soil attributes or with each other;

4. $\mathrm{Cu}, \mathrm{Fe}, \mathrm{Mn}$ and $\mathrm{Zn}$ show medium to strong spatial dependence in the surface and subsurface layers;

5. The determined ranges are greater for the $\mathrm{Cu}$ and $\mathrm{Fe}$ content in the surface horizons (41.25 and $72.16 \mathrm{~km}$ respectively), and around ten times smaller for $\mathrm{Cu}$ and $\mathrm{Fe}$ in the subsurface horizons and for $\mathrm{Mn}$ and $\mathrm{Zn}$ at both depths.

\section{ACKNOWLEDGEMENTS}

The authors wish to thank Petrobrás for their financial support of this study. The authors would also like to thank Capes for the masters scholarship, and CNPq for the research productivity grant (UFPI).

\section{REFERENCES}

ALVAREZ V., V. H. et al. Interpretação dos resultados das análises de solos. In: Comissão de fertilidade do solo do Estado de Minas Gerais. Recomendações para o uso de corretivos e fertilizantes em Minas Gerais: $5^{\text {a }}$ aproximação. Viçosa, MG, 1999. p. 25-32.

AQUINO, R. P. de et al. Análise da vulnerabilidade natural e do risco de degradação no alto curso do rio Banabuiú-CE. Revista Brasileira de Geografia Física, v. 9, n. 2, p. 601-613, 2016.

BIONDI, C. M. et al. Teores de Fe, Mn, Zn, Cu, Ni e Co em solos de referência de Pernambuco. Revista Brasileira de Ciência do Solo, v. 35, n. 3, p. 1057-1066, 2011

CAHN, M. D.; HUMMEL, J. W.; BROER, B. H. Spatial analysis of soil fertility for site-specific crop management. Soil Science Society of America Journal, v. 58, n. 4, p. 1240-1248, 1994

CAMARGO, O. A. de. Reações e interações de micronutrientes no solo. 2006. Disponível em: <http://www.infobibos.com/ Artigos/2006_3/Micronutrientes/Index.htm>. Acesso em: 21 jun. 2016

CARVALHO, V. G. B.; NASCIMENTO, C. W. A.; BIONDI, C. M. Potencial de fertilizantes e corretivos no aporte de micronutrientes ao solo. Revista Brasileira de Ciência do Solo, v. 36, n. 3, p. $931-938,2012$.

CHAVES, L. H. G.; FARIAS, C. H. de A. Variabilidade espacial de cobre e manganês em Argissolo sob cultivo de cana-de-açúcar. Revista Ciência Agronômica, v. 40, n. 2, p. 211-218, 2009. 
COMPANHIA DE PESQUISA DE RECURSOS MINERAIS (BRASIL). Mapa geodiversidade do estado do Ceará. Fortaleza: CPRM - Serviço Geológico do Brasil, 2014. Disponível em: http://www.cprm.gov.br/publique/media/geodiversidade_ceara. pdf. Acesso em: 03 jun. 2016.

EMPRESA BRASILEIRA DE PESQUISA AGROPECUÁRIA. Manual de análises químicas de solos, plantas e fertilizantes. 2. ed. Brasília: Embrapa Informação Tecnológica, 2009. 627 p.

ENVIRONMENTAL SYSTEMS RESEARCH INSTITUTE. ArcGIS Desktop: release 10.2. Redlands, Califórnia, USA: ESRI, 2014.

GAMMA DESIGN SOFTWARE. Geoestatistics for the environmental sciences. Version 7.0. Michigan, 2004. 1 CD-ROM.

GIONGO, V. et al. Decomposição e liberação de nutrientes de coquetéis vegetais para utilização no semiárido brasileiro. Revista Ciência Agronômica, v. 42, n. 3, p. 611-618, 2011.

GUIMARÃES, C. C. B.; VALLADARES, G. S.; MARTINS, C. M. Uso da terra e declividade no sertão central do Ceará, Brasil. Revista Nordestina de Biologia, v. 24, n. 1, p. 3-18, 2016.

LADO, L. R.; HENGL, T.; REUTER, H. I. Heavy metals in European soils: a geostatistical analysis of the FOREGS Geochemical database. Geoderma, v. 148, n. 2, p. 189-199, 2008.

LIMA, R. P. et al. Aporte e decomposição da serapilheira na Caatinga no sul do Piauí. Floresta e Ambiente, v. 2, n. 1, p. 4249, 2015.

MELO, A. A. B. et al. Spatial distribution of organic carbon and humic substances in irrigated soils under different managements systems in a semi-arid zone in Ceará, Brazil. Semina: Ciências Agrárias, v. 37, n. 4, p. 1845-1856, 2016.

MLAMBO, D; NYATHI, P. Litterfall and nutrient return in a semi-arid southern African savanna woodland dominated by Colophospermum mopane. Plant Ecology, v. 196, n. 1, p. 101110, 2008.

MORAIS, E. R. C.; OLIVEIRA, A. A. S.; MAIA, C. E. Qualidade do solo cultivado com banana irrigada e sua relação com áreas de caatinga. Revista Brasileira de Engenharia Agrícola e Ambiental, v. 18, n. 9, p. 887-891, 2014.

NOVAIS, R. F. et al. Fertilidade do Solo. 1. ed. Viçosa, MG: Sociedade Brasileira de Ciência do Solo, 2007, 1017 p.
PIERANGELI, M. A. P. et al. Teores de As, $\mathrm{Pb}, \mathrm{Cd}$ e $\mathrm{Hg}$ e fertilidade de solos da região do alto Guaporé, sudoeste do Estado de Mato Grosso. Acta Amazonica, v. 39, n. 1, p. 61-70, 2009.

RYAN, J. et al. Micronutrient constraints to crop production in the middle east-west Asia region: significance, research, and manegement. Advances in Agronomy, v. 122, p. 1-84, 2013.

SHARMA, A. et al. Zinc: an indispensable micronutrient. Physiology and Molecular Biology of Plants, v. 19, n. 1, p. 11-20, 2013.

SILVA, F. A. S.; AZEVEDO, C. A. V. The Assistat Software Version 7.7 and its use in the analysis of experimental data. African Journal of Agricultural Research, v. 11, n. 39, p. 3733-3740, 2016.

SOBRADO, M. A. Soil and leaf micronutrient composition in contrasting habitats in podzolized sands of the Amazon region. American Journal of Plant Sciences, v. 4, n. 10, p. 1918-1923, 2013.

STEVEnson, F. J.; COLE, M. A. Cycles of soil: carbon, nitrogen, phosphorus, sulfur, micronutrients. 2. ed. NewYork: Wiley-Interscience, 1999. 448 p.

TEKIN, A. B. et al. Spatial structure of available micronutrient contents and their relationships with other soil characteristics and corn yield. Fresenius Environmental Bulletin, v. 20, n. 3, p. 783-792, 2011.

VALLADARES, G. S. et al. Variabilidade espacial e disponibilidade de cobre e zinco em solos de vinhedos e adjacências. Bragantia, v. 68, n. 3, p. 733-742, 2009.

VALLADARES, G. S. Levantamento pedológico de reconhecimento de alta intensidade dos solos e aptidão agrícola do sertão central do Ceará. 2014. 134 f. Relatório técnico, 2014.

VIEIRA, S. R. et al. Handbook for geostatistical analysis of variability in soil and meteorological parameters. In: ALVAREZ, V. H. et al. (Ed.). Tópicos em ciência do solo. Viçosa, MG: Sociedade Brasileira de Ciência do Solo, 2002. v. 2, p. 1-45.

ZIMBACK, C. R. L. Análise espacial de atributos químicos de solos para fins de mapeamento da fertilidade. 2001. 114 f. Tese (Livre Docência) - Faculdade de Ciências Agronômicas, Universidade Estadual Paulista, Botucatu, 2001. 